\title{
Ommatius nanciae, a new species from Ecuador (Diptera, Asilidae, Ommatinae)
}

\author{
Rodrigo Vieira
}

Instituto Nacional de Pesquisas da Amazônia - INPA, Coordenação de Biodiversidade, 69060-000, Manaus, Amazonas, Brazil (rodrigo08vieira@gmail.com)

ABSTRACT. A new species of Ommatius Wiedemann, 1821 is described from Ecuador. The habitus, male and female terminalia are described and illustrated.

KEYWORDS. Holosericeus complex, Neotropical, taxonomy.

RESUMO. Ommatius nanciae, uma nova espécie do Equador (Diptera, Asilidae, Ommatiinae). Uma nova espécie de Ommatius Wiedemann, 1821 é descrita para o Equador. O hábito, as terminálias masculina e feminina são descritos e ilustrados.

PALAVRAS-CHAVE. Complexo holosericeus, Neotropical, taxonomia.

Ommatiinae, one of 14 subfamilies of Asilidae, is characterized by the setae on anterior surface of antennal stylus (Dikow, 2009). The subfamily contains 11 genera: Afroestricus Scarbrough, 2005, Cophinopoda Hull, 1958, Emphysomera Schiner, 1866, Merodontina Enderlein, 1914, Michotamia Macquart, 1838, Ommatius Wiedemann, 1821, Ommatomyia Scarbrough \& Tomasovic, 2010, Pseudomerondontina Joseph \& Parui, 1976, Pygommatius Scarbrough \& Marascia, 2005, Stenommatius Matsumura, 1916, Thallosia Oldroyd, 1970 (Scarbrough \& Tomasovic, 2010). Ommatius, the only genus that occurs in the Neotropical region, has 317 valid species to the world (VIEIRA et al., 2010; Geller-Grimm, 2015) and 117 for the Neotropical region (VIEIRA et al., 2004, 2005, 2010, 2011; PAPAVERo, 2009). It is recognized by the subfamily autapomorphy, setae on anterior surface of antennal stylus (Dikow, 2009) and a sclerotized postmetacoxal bridge (Hull, 1962; Wood, 1981). The genus has eight species groups (ampliatus and holosericeus - holosericeus complex - costatus, hanebrinki, lucidatus, normus, pumilus, tibialis) (SCARBROUGH, 1990, 1993, 2000, 2002, 2008; SCARBROUGH \& Perez-Gelabert, 2006).

The ampliatus group has 21 described species (SCARBROUGH, 2002; VIEIRA et al., 2011) with records from middle Mexico south to northern Argentina, three of which occur in Ecuador. Members of ampliatus group possess the middle femur with two anteroventral macrosetae; presence of a prominent preapical, posterodorsal macroseta; epandrium without a digitate preapical process and females possess apical margin of sternite VIII moderately to strongly produced, and sternite IX usually with small or large oval depressions (SCARBROUGH, 2002).

In this paper, a new species of Ommatius of ampliatus group from Ecuador is described.

\section{MATERIAL AND METHODS}

This study is based on the examination of specimens housed in Staatliches Museum für Naturkunde (SMNS), Stuttgart, Germany. Morphological terminology follows Cumming \& Wood (2009), except for setae and macrosetae. The term "macrosetae" refers to setae relatively thick and with well-developed socket.

The techniques of VIEIRA (2012) were used to examine the terminalia. After examination and illustration, the detached parts were placed in microvials with glycerin and pinned with their respective specimen. The label data are cited in full, with the original spellings, punctuation, and dates. Information presented within square brackets is complementary data not included on the labels. Data from the same specimen but from different labels are separated by slashes (/).

\section{RESULTS}

\section{Ommatius nanciae sp. nov.}

(Figs 1-12)

Diagnosis. Ten to twelve black postocular macrosetae; femora black with narrow bases yellow (Figs 1,9); apex of epandrium triangular in lateral view (Fig. 3); gonostylus narrow in lateral view, curved apically, apex pointed (Figs 3, 5, 7); gonocoxite wide with 1 long, thick macroseta (Figs 3, 5, 7); apical 1/2 of ejaculatory apodeme with a crest dorsally (Fig. 8); female sternite VIII slightly produced medially with five long and thick macrosetae (Fig. 11); spermathecae oval, surface with streaks (Fig. 12).

Description. Male, holotype. Head. Antenna black; two black ocellar setae; vertex, frons and face black, face 

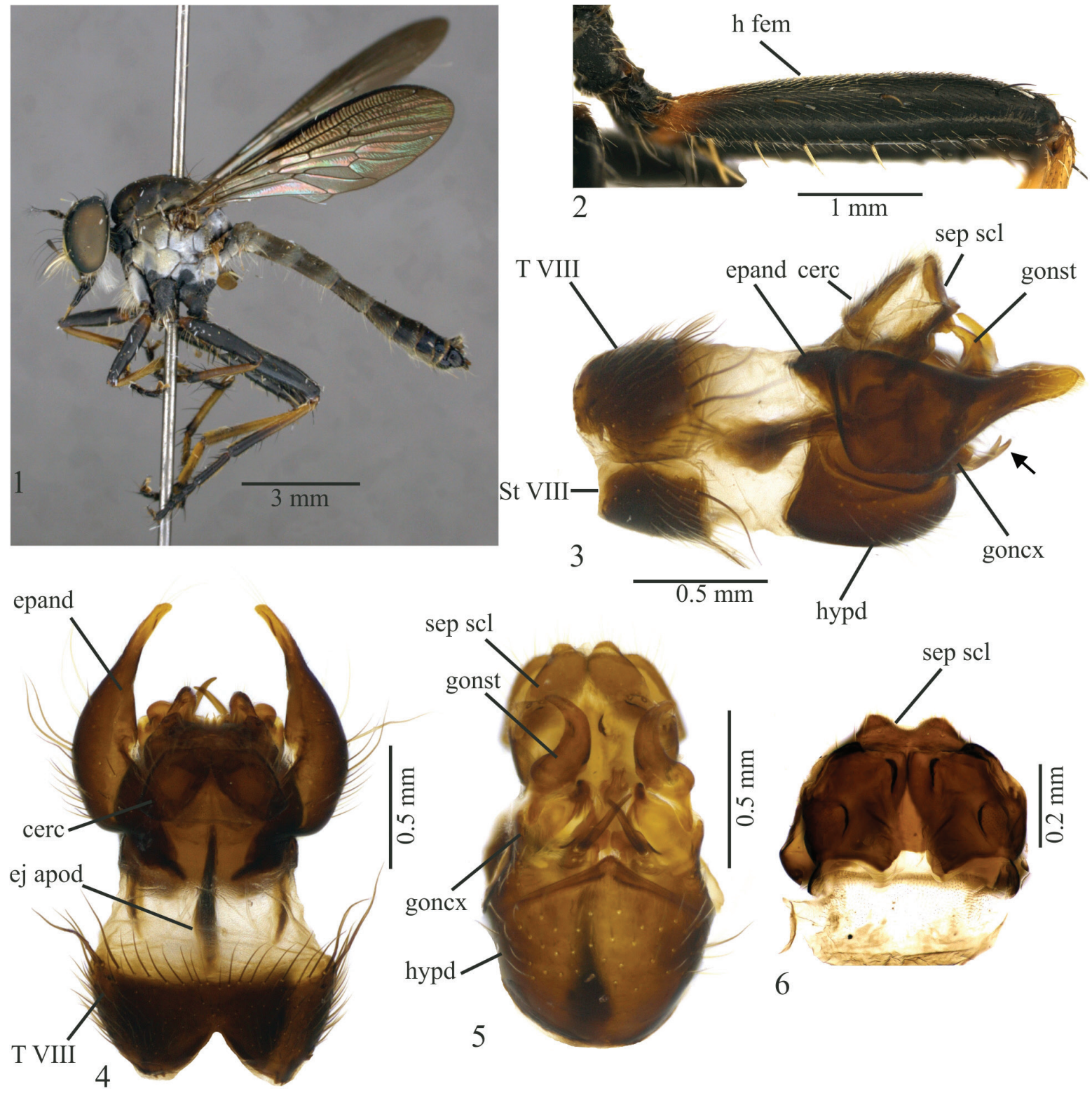

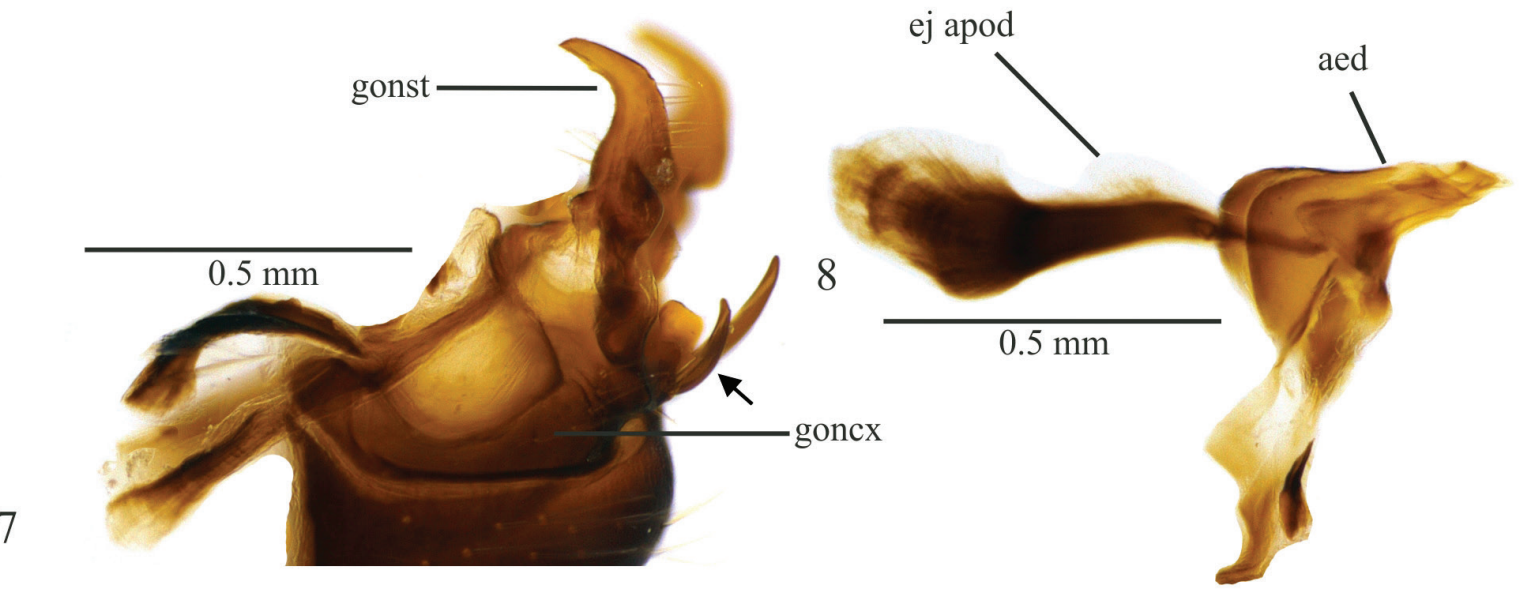

Figs 1-8. Ommatius nanciae sp. nov., holotype male: 1, habitus, lateral view; 2, hind femur; 3, terminalia, lateral view; 4, terminalia, dorsal view; 5 , terminalia, ventral view, without epandrium; 6 , subepandrial sclerite; 7 , gonostylus, gonocoxite and hypandrium, lateral view; 8 , aedeagus, lateral view (aed, aedeagus; cerc, cercus; ej apod, ejaculatory apodeme; epand, epandrium; goncx, gonocoxite; gonst, gonostylus; h fem, hind femur; hypd, hypandrium; TVIII, tergite VIII; sep scl, subepandrial; st VIII, sternite VIII). 

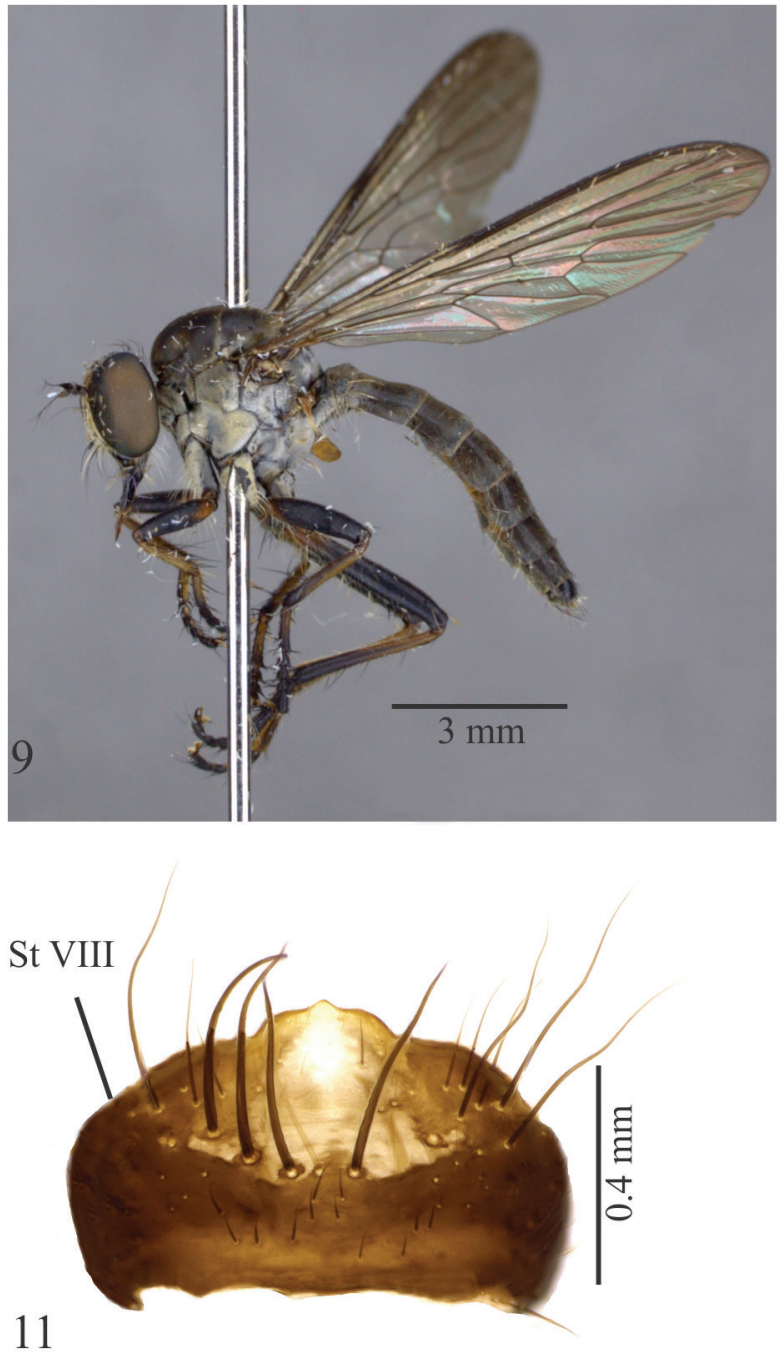

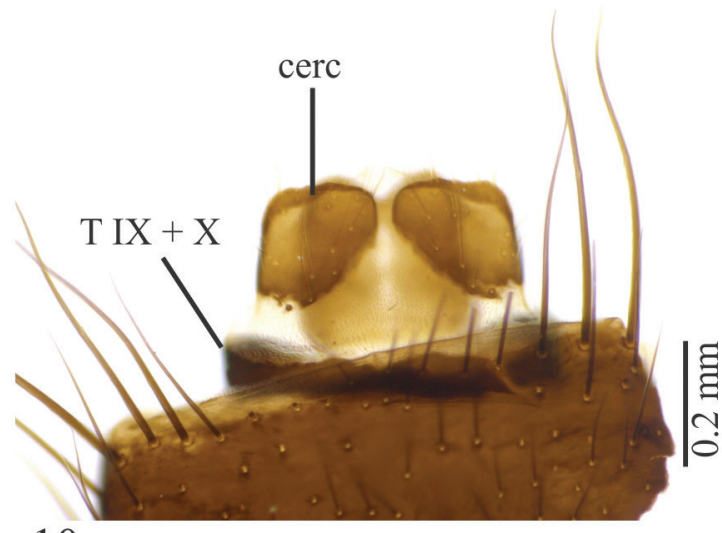

10

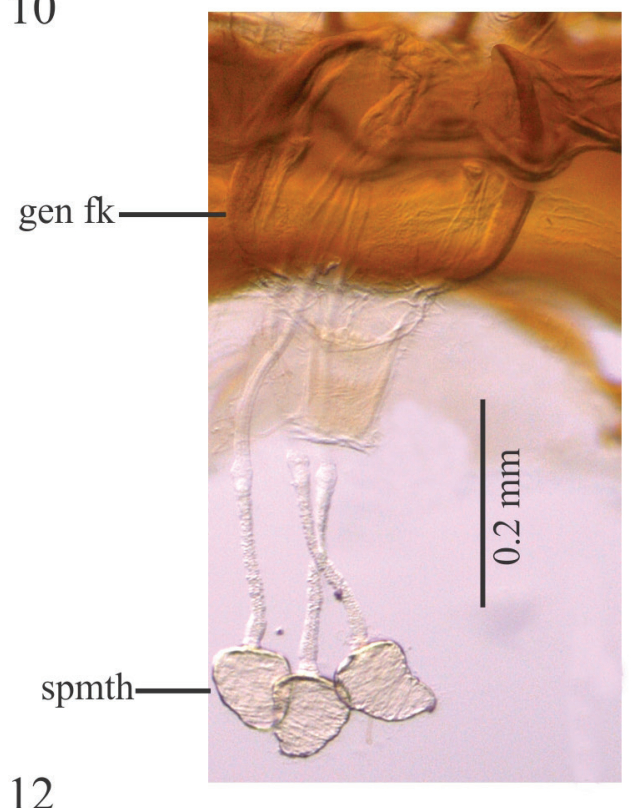

Figs 9-12. Ommatius nanciae sp. nov. 9, Habitus female, lateral view; 10, tergite IX+X and cercus; 11, sternite VIII; 12, genital fork and spermathecae (cerc, cercus; gen fk, gential fork; T IX+X, tergite IX+X; spmth, capsule of spermathecae; St VIII, sternite VIII).

golden tomentose; mystax with black and yellow setae; palpus brown, yellow setose; proboscis black, yellow setose ventrally, labial setae yellowish; occiput black, silvery tomentose with white setae; 10-12 black postocular macrosetae.

Thorax. Antepronotum and postpronotum black with white setae; mesonotum black dorsally, brown tomentose; sutural, prescutellar and postalar spot, pleuron gray tomentose, scutellum brown tomentose. Chaetotaxy: 1 yellow anepimeral seta; 2 black notopleural macrosetae; 1 black supra-alar macroseta; 1 black postalar macroseta; 3 pairs of black postsutural dorsocentral macrosetae; anatergal setae absent; 2 black apical scutellar setae; discal scutellar setae yellow; katatergal macrosetae yellow; posterior meron + metanepisternum entirely yellowish setose.

Wing. Brown; without costal dilation; crossvein $\mathrm{r}-\mathrm{m}$ before middle of cell $\mathrm{d} ; \mathrm{R}_{4+5}$ beyond apex of cell $\mathrm{d}$; microtrichia on posterior wing margin arranged in a single row; halter pale yellow.
Legs (Fig. 1). Femora black, narrow bases yellow; fore tibia yellow, apex black; mid tibia with basal $4 / 5$ yellow and apical 1/5 black; hind tibia with basal 1/2 yellow and apical $1 / 2$ brown to black; tarsomeres black, except first tarsomere of fore and mid tarsi with basal $3 / 4$ yellowish. Chaetotaxy: fore femur setose ventrally; mid femur with 2 black setae anteroventrally, 3 black setae anteriorly and 1 black apical seta dorsoposteriorly; right hind femur with setae as follows: 3 yellow basoanteroventrally, 3 black apically, 2 yellow anteriorly, and 1 black seta dorsoposteriorly (Fig. 2); 5 black setae posteroventrally; left hind femur basal setae with 1 basal yellow and 1 basal black setae anteroventrally and 2 black and 1 yellow apically; fore tibia with 2 long yellow setae posteriorly; mid tibia with 2 anterior black setae and 2 black anteroventral setae; hind tibia with 4 black setae dorsally and 1 apical spur-like macroseta; tarsomeres largely black setose, 1 yellow seta on first tarsomere of the fore leg. 
Abdomen. Black with predominant yellow setae (Fig 1). Tergite VIII with median concavity (Fig. 4).

Terminalia. Black, except brown apex of epandrium, apical margin of gonocoxite and gonostylus (Fig. 1); epandrium with apical 1/3 narrow (Figs 3,4); basal 1/2 of inner margin of epandrium emarginate in dorsal view (Fig. 4); basal margin of epandrium narrow and pointed (Fig. 4); apex of epandrium triangular in lateral view (Fig. 3); apical margin of cercus truncate (Fig. 4); gonostylus narrow, curved apically, apex pointed in lateral view (Figs $3,5,7$ ); gonocoxite wide, with 1 long, thick macroseta (Figs $3,5,7)$; basal $1 / 2$ of ejaculatory apodeme wide, apical $1 / 2$ with a crest dorsally (Fig. 8); aedeagus: straight to body axis; (Fig. 8); apical margin of hypandrium triangular (Fig. $5)$; subepandrial sclerite with concavity on the medial apical margin (Fig. 6).

Length. Body $11.5 \mathrm{~mm}$; wing $9.1 \mathrm{~mm}$.

Female. (Figs 9-12): similar to male, except for body length: $10.2 \mathrm{~mm}$, wing $9.7 \mathrm{~mm}$; crossvein $\mathrm{r}-\mathrm{m}$ beyond middle of cell d; mid tibia with basal 4/5 brown; hind tibia with basal 1/2 brown (Fig. 9); right hind femur with 3 basal yellow setae anteroventrally and 2 black basal, 2 black and 1 yellow apical macrosetae posteroventrally; left hind femur with 3 yellow and 1 black basal setae anteroventrally and 2 black and 1 yellow apical macrosetae posteroventrally; hind tibia without apical spur-like macroseta; tarsomeres with black setae; abdomen brown to black with predominant yellow setae (Fig. 9). Tergite IX +X short dorsally (Fig. 10); apical margin of cercus truncate (Fig. 10); sternite VIII slightly produced medially with 5 long, thick macrosetae (Fig. 11); furcal apodeme short, platelike (Fig. 12); spermathecae oval, surface streaked (Fig. 12).

Etymology. This species is dedicated to my mother, Nanci Marques Vieira.

Holotype conditions. In good conditions.

Distribution. Ecuador: Zamora-Chinchipe Province.

Type material. Holotype, ECUADOR, ZamoraChinchipe, Rio San Francisco, Estácion Científica San

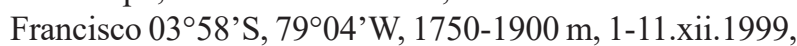
D. Bartsch \& C. Häuser leg./ Holotype Ommatius nanciae (ð SMNS). Paratype: Same data as holotype/ Paratype Ommatius nanciae (1q SMNS).

\section{DISCUSSION}

Ommatius nanciae sp. nov. is assigned to the ampliatus species group because it shares the diagnostic characteristics of this group. Ommatius nanciae sp. nov. is distinguished from congeners [O. angustatus Scarbrough, 2002, O. destitutus Scarbrough, 2002, O. fernandezi Scarbrough, 2002, O. triangularis Scarbrough, 2002, O. tucumanensis Scarbrough, 2002 and O. unguiculatus Scarbrough, 2002] by the colour of hind femur and the combined characters of the terminalia. Further $O$. nanciae sp. nov. has a black hind femur with a narrow yellow base whereas it is largely yellow in the above species.
Ommatius nanciae sp. nov. differs from O. aubreyi Vieira, Bravo \& Rafael, 2011, O. ayalai Scarbrough, 2002, O. bullatus Scarbrough, 2002, O. constrictus Scarbrough, 2002, O. depressus Scarbrough, 2002, O. flexus Scarbrough, 2002 and O. lunatus Scarbrough, 2002 by 5 black posteroventrally setae on the hind femora, whereas these species possess basal 3-4 yellow posteroventral setae on the hind femora.

The black fore and middle femora with narrow yellow bases distinguishes Ommatius nanciae sp. nov. from O. quadratus Scarbrough, 2002, O. ovatus Scarbrough, 2002, O. angulosus Scarbrough, O. dolabriformis Scarbrough, 2002, O. tropidus Scarbrough, 2002 and $O$. tanpadiensis Scarbrough, 2002 which have the fore and middle femora at least yellow on basal 1/3-1/2 posteriorly. Ommatius nanciae sp. nov. can be separated from $O$. ampliatus Scarbrough, 2002 by the epandrium narrowed apically, apex pointed; gonocoxite with 1 long and thick macroseta and spermathecae oval. In $O$. ampliatus, the epandrium is slightly expanded apically, clavate, apex rounded, gonocoxite with 3 long, thin setae and spermatheca spherical.

Ommatius nanciae sp. nov. is distinguished from O. gladiatus Scarbrough, 2002 by the narrow gonostylus in lateral view, curved apically, apex pointed; basal 1/2 of ejaculatory apodeme wide, apical $1 / 2$ with a crest dorsally; female sternite VIII slightly produced apically and the spherical spermatheca. Ommatius gladiatus is distinguished by the apical $1 / 3$ of the gonostylus is narrow, angular, and much wider basally; gonocoxite with only setae; ejaculatory apodeme narrow; female sternite VIII strongly produced apically and spherical spermatheca.

Acknowledgments. The author acknowledge the financial support from Fundação de Amparo à Pesquisa do Estado do Amazonas (FAPEAM) and Conselho Nacional de Desenvolvimento Científico e Tecnológico (CNPq) (Proc. 1437/2007), CNPq/PNPD (Proc. 560987/20102); FAPEAM (Proc. 062.00745/2014); CNPq/PNPD Process $n^{\circ}$ : 560987/2010-2, CNPq Process n ${ }^{\circ}: 401.243 / 2012-5$, FAPEAM EDITAL N. 022/2013-FIXAM/AM Process no : 062.00745/2014; Dr Hans-Peter Tschorsnig, curator of SMNS, for the loan of specimens; anonymous reviewer for helpful comments that improved the manuscript and Dr. Aubrey Scarbrough for his invaluable assistance with this work.

\section{REFERENCES}

Cumming, J. M. \& Wood, D. M. 2009. Adult morphology and terminology. In: Brown, B. V.; Borkent, A.; Cumming, J. M.; Wood, D. M.; Woodley, N. E. \& Zumbado, M. A. eds. Manual of Central American Diptera. Ottawa, National Research Council Research Press, v.1, p. 9-50.

Dikow, T. 2009. Phylogeny of Asilidae inferred from morphological characteristics of imagines (Insecta: Diptera: Brachycera: Asiloidea). Bulletin of the American Museum of Natural History 319:1-175.

Geller-Grimm, F. 2004. Catalog of species. Available at: <http://www. geller-grimm.de/catalog/specieshtm>. Accessed on: 29 March 2010.

Hull, F. M. 1962. Robber Flies of the World: The Genera of the Family Asilidae. Washington D. C., Smithsonian Institution, United States National Museum, Bulletin 224, Part 2, p. 431-906.

Papavero, N. 2009. Catalogue of Neotropical Diptera. Asilidae. Neotropical Diptera 17:1-179. 
Scarbrough, A.G. 1990. Revision of the New World Ommatius Wiedemann (Diptera: Asilidae). I. The pumilus species group. Transactions of the American Entomological Society 116:65-102. 1993. Revision of the New World species of Ommatius Wiedemann (Diptera: Asilidae): the Neotropical costatus species group. Revista de Biología Tropical 41:729-753.

2000. Two additional species of robber flies of the Ommatius Wiedemann (Diptera: Asilidae) from the Bahamas and with replacement names for two other species. Proceedings of the Entomological Society of Washington 102:912-918.

2002. Synopsis of the Neotropical holosericeus complex of the genus Ommatius Wiedemann (Diptera): ampliatus and holosericeus species group. Transactions of the American Entomological Society 128: $133-222$

2008. New Ommatius Wiedemann from the Americas with two new species groups, keys, and taxonomic notes (Diptera: Asilidae). Insecta Mundi 32:1-14.

2010. An overview of the Afrotropical Ommatiinae (Diptera: Asilidae) with a key to genera. Zootaxa 2540:1-47.

Scarbrough, A. G. \& Perez-Gelabert, D. E. 2006. A review of the asilid (Diptera) fauna from Hispaniola with six genera new to the island, fifteen new species, and checklist. Zootaxa 1381:1-91.
Scarbrough, A. G. \& Tomasovic, G. 2010. Ommatomyia, a new genus from Vietnam (Diptera: Asilidae: Ommatiinae). Zootaxa 2366:46-54.

VIEIRA, R. 2012. A new species of Leinendera Carrera, 1945 (Diptera, Asilidae, Asilinae) from Brazil. Biota Neotropica 12(3):1-7.

Vieira, R.; Castro, I. \& Bravo, F. 2004. Two new species of Ommatius Wiedemann (Diptera: Asilidae) from Brazil. Zootaxa 764:1-7. .2005. A new species of Ommatius Wiedemann (Diptera: Asilidae) from Brazil. Zootaxa 1017:19-24.

VieIRA, R.; Bravo, F. \& RAFAEL, J.A. 2010. Ommatius Wiedemann, 1821, normus species-group (Diptera, Asilidae): description of two new species and comments on Brazilian species. Zootaxa 2344:39-51.

2011. O complexo holosericeus de Ommatius Wiedemann no Brasil: nova espécie e primeiro registro do grupo ampliatus para o País e novos registros para o grupo holosericeus (Diptera, Asilidae). Revista Brasileira de Entomologia 55:549-559.

Wood, G. C. 1981. Asilidae. In: McAlpine, J. F.; Peterson, B. V.; Shewell, G. E.; Teskey, H. J.; Vockeroth, J. R. \& Wood, D. M. eds. Manual of Neartic Diptera. Ottawa, Agriculture Canada Monograph, 27, v.1., p. 549-573. 